\title{
Biodiversity of subterranean termites on the Acacia crassicarpa plantation
}

\author{
NOOR FARIKHAH HANEDA ${ }^{1, \vartheta}$, ICHMA YELDHA RETMADHONA ${ }^{2}$, DODI NANDIKA ${ }^{3}$, ARINANA ${ }^{3}$ \\ ${ }^{1}$ Department of Silviculture, Faculty Forestry, Institut Pertanian Bogor. Darmaga Campus, Bogor16680, West Java, Indonesia \\ Tel./fax.: +62 -251-8626806/8626886, `email: nhaneda@yahoo.com \\ ${ }^{2}$ Graduate Program in Silviculture, Faculty of Forestry, Institut Pertanian Bogor. Darmaga Campus, 16680, West Java, Indonesia \\ ${ }^{3}$ Departmen of Forest Product, Institut Pertanian Bogor. Darmaga Campus, Bogor 16680, West Java, Indonesia.
}

Manuscript received: 25 Mei 2017. Revision accepted: 24 October 2017.

\begin{abstract}
Haneda NF, Retmadhona IY, Nandika D, Arinana. 2017. Biodiversity of subterranean termites on the Acacia crassicarpa plantation. Biodiversitas 18: 1657-1662. The development of industrial plantation forests is one of the efforts to meet the needs of raw material of processing industry of timber forest products. In the last 15 years, the development of industrial plantation forest has grown rapidly. Plant species widely developed is fast-growing plants (fast growing trees) such as Acacia crassicarpa Cunn ex Benth. However, A. crassicarpa has a low resistance against pests, evidenced by the presence of subterranean termites attack occurred in the industrial plantation forest of A. crassicarpa. This aim of the study is to determine the diversity of subterranean termites in plantation forest of $A$. crassicarpa. Two methods used for data collection: baiting system and survey. Five species of subterranean termites found on sample paths were Coptotermes curvignathus Holmgren, C. gestroi Wasmann, Schedorhinotermes javanicus Kemner, Longipeditermes longipes Haviland, and Pericapritermes mohri Kemner. These species can be distinguished from the morphology of the mandible. Coptotermes is most commonly found Genus in study plots.
\end{abstract}

Keywords: Acacia crassicarpa, baiting system, Coptotermes curvignathus, fast-growing trees, survey

\section{INTRODUCTION}

The development of industrial plantation forests is one of the efforts to meet the raw material needs of processing industry of timber forest products. In the last 15 years, industrial plantation forest has grown rapidly. The plantation area increased from 1.13 million ha in 1995 to 9.97 million ha in 2009 (Sumargo et al. 2011). Plant species widely developed is the fast-growing plants (fast growing species) because they have a relatively short harvest period. Acacia crassicarpa is one of the plants that has many advantages. Thus they are widely used in pulp and paper industries. A. crassicarpa is one of the major tropical Australian and South-East Asia, especially in Indonesia and Vietnam (Lam et al. 2014). The fiber of the plant is in the category of medium to high and the yield is quite higher compared to Acacia mangium (Sugesty et al. 2015). In addition, highly adaptive to the extreme environment, makes it very easy to plant in peat. According to Suhartati et al. (2014) this species is able to grow well in the marginal land condition (in swamps, or in an area flooded periodically) with high organic matter content and low $\mathrm{pH}$. The plant began to be developed and grown on a large scale in various areas of industrial plantation forest. However, Acacia is included in the category of low durability wood, which makes it very vulnerable to pest attacks. As reported by Hutabarat et al. (2015), some trees are potentially attacked by pests, especially termites such as rubber, pine, eucalyptus, acacia, and palm oil.

It is also recently reported that $A$. crassicarpa plantations in Riau has been attacked by termites (Tjahjono
2016 (personal communication)). Termites attack has caused death on some stands, which should be a particular concern in the future. Termites are known as pests that attack the building and construction, but in some cases, subterranean termites also potentially become a pest in plantations, agriculture, and industrial plantation forests. One example of the plantations potentially attacked by subterranean termites is palm oil. Arinana et al. (2012) identified three species of termites attacking the palm oil plantation in Bogor, namely: Macrotermes gilvus, Coptotermes curvignathus, and Nasutitermes javanicus. Another subterranean termites attacks on plantation forests have been reported by Ngatiman (2014) and Herlinda et al. (2010). Subterranean termites have invaded meranti plantation forest in East Kalimantan and community-owned rubber plantations in West Sumatra.

One of the termites species that should be taken into account is Coptotermes species. The termites have a very large population and wide range of habitat. Coptotermes is also known to be very greedy and harmful (Nandika 2015). Moreover, not all species of subterranean termites are harmful, some species of subterranean termites are needed in nature as decomposers. Therefore, proper identification is needed for effective control. The necessity to conduct a study of the diversity of subterranean termites, especially in plantations A. crassicarpa gives an important information in designing the pest control of subterranean termites. The purpose of this study is to determine the diversity of subterranean termites in the industrial plantation forest of A. crassicarpa. 


\section{MATERIALS AND METHODS}

\section{Study area}

Specimen collection of subterranean termite was conducted for 5 months from May to September 2016 in Bukit Batu Subdistrict, Bengkalis District, Riau Province, Indonesia. The specimen was identified in Forest Entomology Laboratory, Department of Silviculture, Faculty of Forestry, Institut Pertanian Bogor, Indonesia. The study site is presented in Figure 1. There were nine sample plots used in this study and they were classified by the age of $A$. crassicarpa stands (1, 2, and 3 years old).

\section{Equipments and materials}

The equipments used in the study were tape measure, digital camera, bottle for termites collection, a binocular microscope with lens of 0.67 to $4.5 \mathrm{x}$ magnification. The main materials used were pine wood cut according to the standard of ASTM-D-1758-96-2008 (ASTM 2008) as stakes in baiting method, and 70\% alcohol.

\section{Procedures}

Sample plots. The plots were set using stratified random sampling methods with intensity sampling of $0.6 \%$ of overall plots (1,500 plots). There were nine sample plots used as study site. One plot has more or less 25 ha of width, thus to shorten the scope of research, two sample paths were made in the sample plot. The sample paths of $250 \mathrm{~m} \times 25 \mathrm{~m}$ were made in transect across contour. Collection of subterranean termite specimens in sample paths was carried out by survey and baiting system.

Baiting system. The baiting system was conducted using pine wood as stakes in accordance with ASTM-D1758-96-2008 (ASTM 2008), which referred to the study by Arinana et al. (2014). A total of 60 wooden stakes were installed in sample paths or 120 wooden stakes in one sample plot. The wooden stake was installed with the distance of $8 \mathrm{~m} \times 6 \mathrm{~m}$ (four trees from the edge of the canal and two trees between wooden stakes in one lane) (Figure 2). Monitoring was done after one month of installation of wooden stakes, then termites attacking the stakes were collected and put into a collecting bottle containing 70\% alcohol.

The stakes were planted vertically into the ground. Half of the stakes was below the soil surface, and the other half was above the ground (Figure 3) to facilitate the monitoring. The upper stakes were coded using lightcolored to facilitate the monitoring activities.

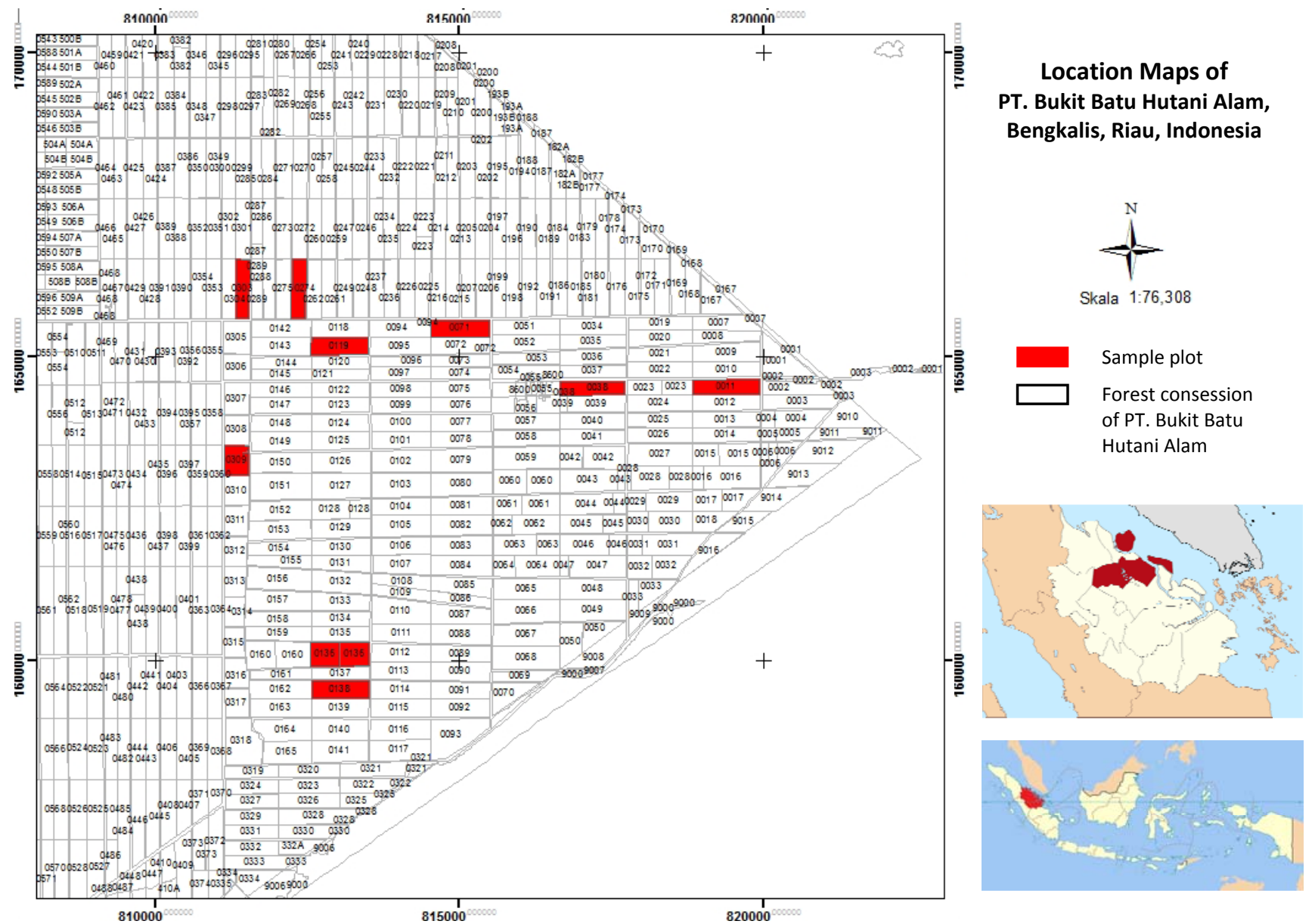

Figure 1. Study site of A. crassicarpa industrial plantation forest, Bukit Batu Subdistrict, Bengkalis District, Riau Province, Indonesia 


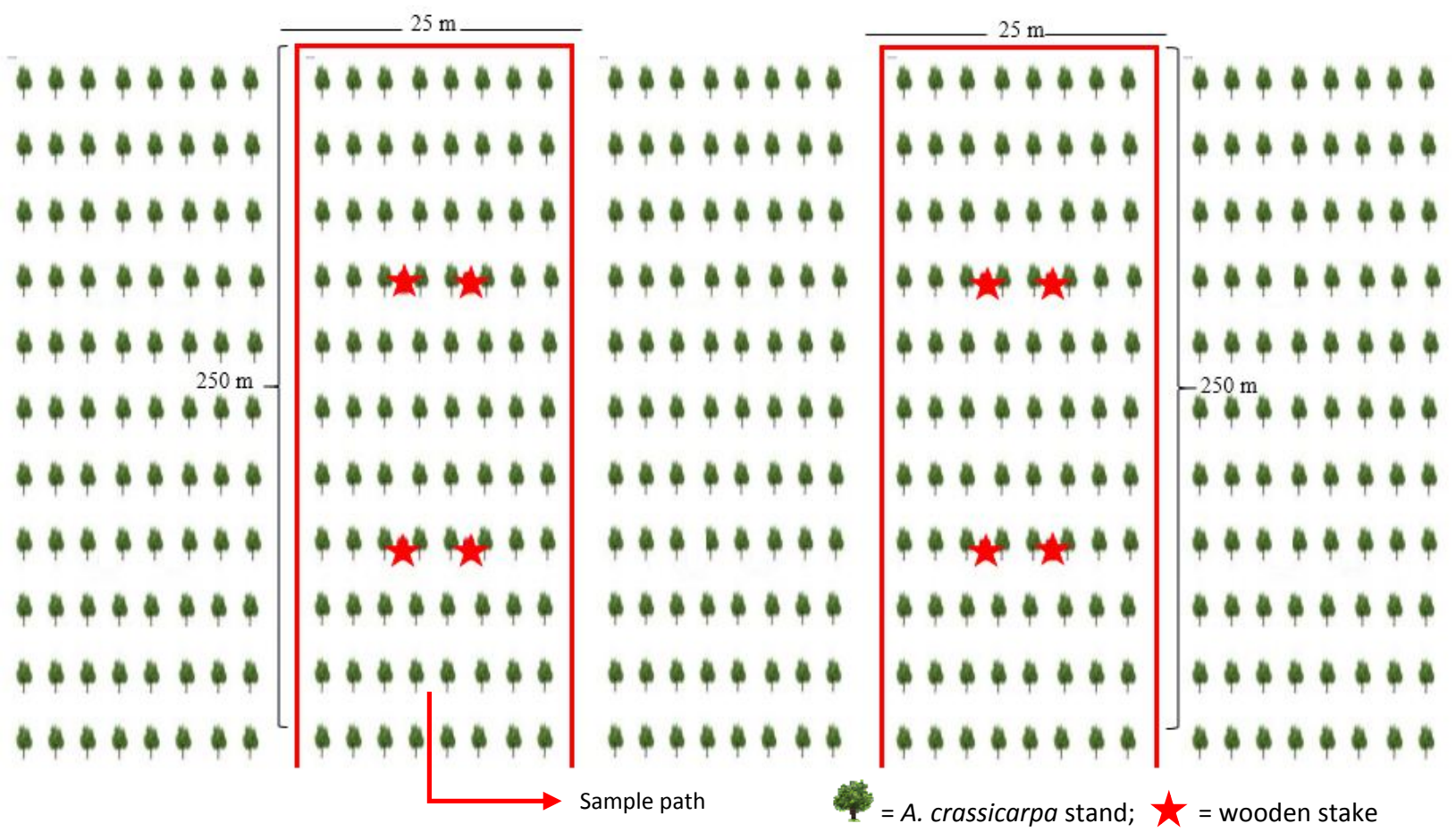

Figure 2. Illustration of bait stake placement in sample paths

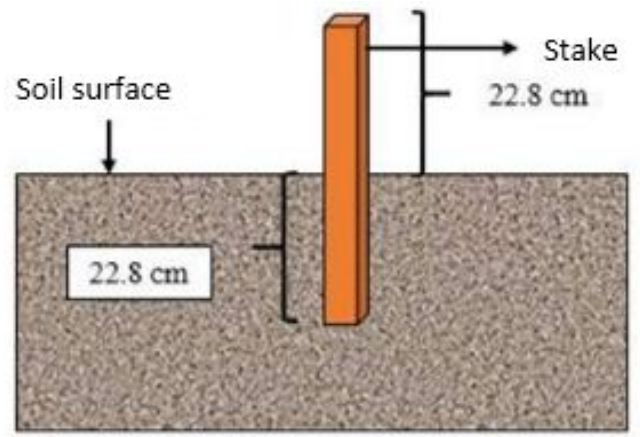

Figure 3. Installation of the stakes

Survey. Survey was conducted by directly observing the physical condition of the tree. The attacked trees were indicated by the presence of tunnel of termites' path on a tree. In addition to the tree condition, the observations were done around the sites such as: logged over stumps and litter. The termites which were from the soldier caste were then collected and put into a collecting bottle. The number of affected trees was recorded. .

Identification. The specimens were identified using a binocular microscope with lens of 0.67 to 4.5 magnification. The termites species determination was performed using the determination key of termites by Tho (1992) and Ahmad (1958). The observation of termites included the entire body, especially on the head (mandible).

\section{RESULTS AND DISCUSSION}

The results of the survey show five species of subterranean termites found in the sample paths namely Coptotermes curvignathus, C. gestroi, Schedorhinotermes javanicus (Family: Rhinotermitidae), Longipeditermes longipes, and Pericapritermes mohri (Family: Termitidae). These five types of subterranean termites can be identified by the shape of the mandible and physical size. In nine sample plots, genus of Coptotermes was found in all sample plots. Compared to other species, Coptotermes have the most extensive attack, i.e. of 17,280 observed trees, 560 A. crassicarpa stands were attacked by Coptotermes. It showed that all the trees were attacked by Coptotermes termites. The distinctive feature of this genus is that when the soldier caste of the colonies is disturbed, their heads will secrete a white liquid. It is a Coptotermes' defense from predators or enemies. Pericapritermes was the fewest termites found in the sample paths. This termite was only found on sample paths with 3 years old of A. crassicarpa stands.

In the bait method, three species termites of family Rhinotermitidae were found namely $C$. curvignathus, $C$. gestroi, and Schedorhinotermes javanicus. A total of 1,080 wooden stakes were installed in nine sample plots, but only 105 wooden stakes were identified to be infested by termites $(9.7 \%)$, of which $91(8.4 \%)$ wooden stakes were attacked by Coptotermes and 14 (1.3\%) by Schedorhinotermes. 


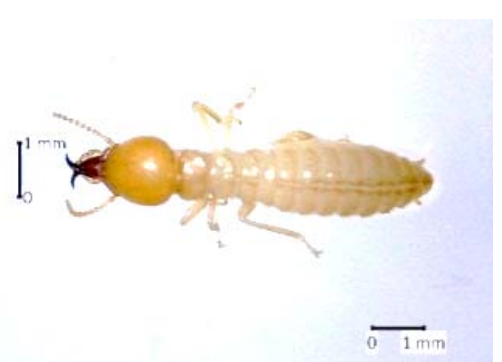

A

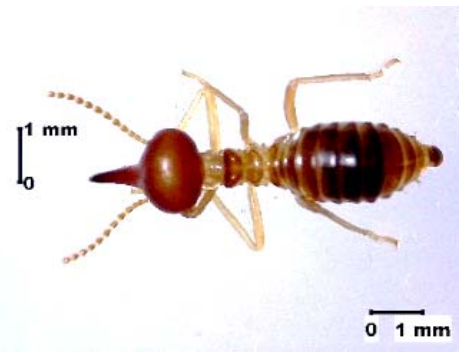

D

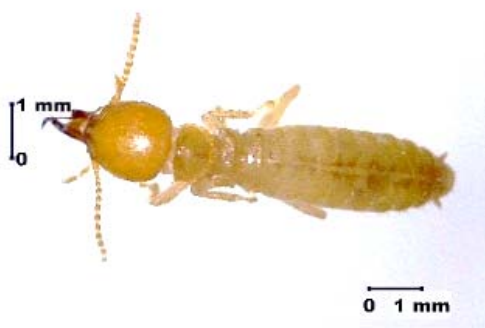

B

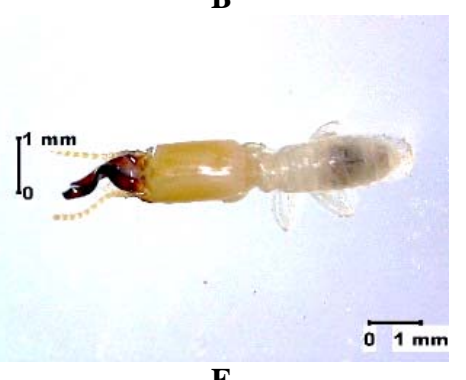

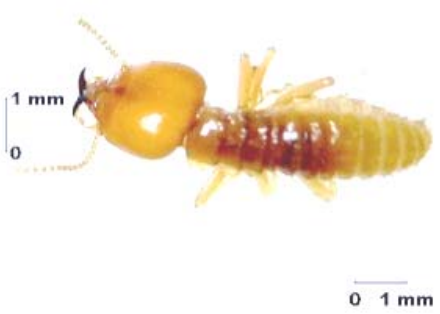

C

Figure 3. Species of subterranean termites: A. C. curvignathus (Holmgren); B. C. gestroi (Wasmann); C. Schedorhinotermes javanicus (Kemner); D. Longipeditermes longipes (Haviland); E. Pericapritermes mohri (Kemner)

Table 1. Species of subterranean termites in Acacia crassicarpa

\begin{tabular}{clll}
\hline $\begin{array}{c}\text { Age of stand } \\
\text { (years) }\end{array}$ & Species of termite & Family & Location \\
\hline $\mathbf{1}$ & Coptotermes curvignathus & Rhinotermitidae & Stand, stump, litter \\
& C. gestroi & Rhinotermitidae & Stand, stump, litter \\
$\mathbf{2}$ & C. curvignathus & Rhinotermitidae & Stand, stump, litter \\
& C. gestroi & Rhinotermitidae & Stand, stump, litter \\
& Schedorhinotermes javanicus & Rhinotermitidae & Stand, stump, litter \\
& Longipeditermes longipes & Termitidae & Dead tree, stump, litter \\
3 & C. curvignathus & & Stand, stump, litter \\
& C. gestroi & Rhinotermitidae & Stand, stump, litter \\
& S. javanicus & Rhinotermitidae & Stand, stump, litter \\
& L. longipes & Rhinotermitidae & Dead tree, stump, litter \\
\hline
\end{tabular}

Coptotermes was commonly found in A. crassicarpa stands, but Longipeditermes and Pericapritermes were not found in these stands. Sample plot with 3 years old of $A$. crassicarpa stands has the largest number of species when compared to sample plots with other standing age. There were five species termites found in sample plots with 3 years old of A. crassicarpa stand. While sample plot with 1-year-old stands have the lowest number of species in which only two species were found. The total number of each termite species were presented in Table 2. Specimens of termites were collected at some points especially on $A$. crassicarpa stands and around the study site. Coptotermes, especially $C$. curvignathus, have the longest body size compared to other types. The next species with long body is S. javanicus. This termite has two types of soldier caste: mayor and minor. The morphology of these two soldier types of $S$. javanicus can be differentiated from the size and color of the body.
Table 2. Number of subterranean termites in A. crassicarpa plantation

\begin{tabular}{llc}
\hline Family & Species & $\begin{array}{c}\text { Number of } \\
\text { termites }\end{array}$ \\
\hline Rhinotermitidae & Coptotermes curvignathus & 198 \\
& $\begin{array}{l}\text { C. gestroi } \\
\text { Schedorhinotermes javanicus }\end{array}$ & 130 \\
& Longipeditermes longipes & 728 \\
Termitidae & Pericapritermes mohri & 33 \\
\hline
\end{tabular}

\section{Discussion}

Differences in the number of subterranean termite species can be caused by several things, such as differences in soil type and inundation of land conditions (Cheng et al. 2008, Kon et al. 2012). According to Cheng et al. (2008), the land with mineral soil type will be dominated by 
members of Termitidae, but the number of its members will be decreased on peatland. In contrast, members of the Rhinotermitidae will dominate on peatlands but their species richness decrease in mineral soil type. However, the history of land use can also affect species richness in an area. Haneda and Firmansyah (2012) also found that the highest diversity occurred in the Termitidae family in the forest area with mineral soil type. In primary forests, the diversity of termites is very high, but decreases in the monoculture forest (Handru et al. 2012). Some studies also show the same phenomenon that the richness of termite species in relatively undisturbed areas is higher than in other areas.

Termites are a very important group of insects in the humid tropics. This colonizing insect has high species diversity and populations. Some species can potentially become pests as they eat the cellulose material. This insect is also known as the destroyer of buildings and constructions made of wood, but in the last century, termites superbly become pests in agriculture, plantation, and forestry. Termites are insect species in the order Isoptera in which about 200 species and 179 species have been identified in Indonesia. Termites are polymorphic which live in a caste system of colonies: breeders, workers, and soldiers. Each caste have the distinctive body with their respective duties in the colony. According to Nandika et al. (2015), this insect can be identified by observing the size of the head and mandible of the soldier caste.

In nature, termites have a very important role as soil macrofauna to make the tunnels on the ground, which makes the soil to have a good porosity for plant growth. Some particular species of termites are able to accelerate the nutrients cycling to improve soil fertility. Termites are one of the critical decomposing organisms for decomposition process in the tropical forests. However, termites also often destroy the wood or attacking trees and crops which affect a big economic loss. Termites are recently problem which is not easy to overcome and have become a big problem due to their increasing attacks intensity. The attacks have a close relationship with the high population number, wide range of habitat and high adaptability to the unfavorable environment.

Coptotermes is a group of subterranean termites nesting below the ground. But unlike other subterranean termites, the group is able to build temporary nests (secondary nest) away from the ground. Therefore, the attack can reach higher parts. Coptotermes is potential termites as a destructive pest of $A$. crassicarpa stands. The termites' existence should be wary. Some cases have been reported by Ngatiman (2014) and Herlinda et al. (2010) that termites do not only damage the wood but also living trees. The attack occurs on the stand causing an injury to death. The diversity of Coptotermes in Indonesia is higher than in other countries. Favorable habitat in tropic is certainly very pleasant habitat for termites. According to Savitri et al. (2016), species that have long been known as wood and building destroyers in Indonesia are C. curvignathus. This insect is able to adapt to various environmental conditions, in addition, it has a large enough population. C. gestroi is endemic termites of South East Asia. The soldier caste has similarities with $C$. formosanus, in which the fontanelle is equal between both mandibles. The difference is in the number of hair on the fontanelle, in which $C$. formosanus has a lot of hair while $C$. gestroi has only one hair. In addition, the morphological shape of fontanelle of $C$. gestroi is more prominent than $C$. formosanus (Subekti 2010). Other biological characteristics of C. formosanus and C. gestroi has also been described by Su et al. (2017).

Schedorhinotermes is a member of Rhinotermitidae family and Rhinotermitinae subfamily. Soldier caste of Schedorhinotermes has two types, i.e. the large soldier (major) and small soldier (minor). S. javanicus is easy to find in the entire java island, up to an altitude of 1000 meters above sea level. This is consistent with the study conducted by Haneda and Firmansyah (2012). They reported that $S$. javanicus has been found in Gunung Walat University Forest at 460-715 meters above sea level. In addition, Schedorhinotermes has a wide range of habitat. Rismayadi (1999) reported that the home range of the termite colony around Institut Pertanian Bogor (IPB) rectorate building reaches $295 \mathrm{~m}$. The termites are commonly found in tree trunks, logged or stumped of wood in the forest. The species can also be found on the islands of Borneo and Sumatra (Gathome-Hardy et al. 2002). In the sample paths, $S$. javanicus is found in litter and stumps but it is very rarely found to attack $A$. crassicarpa stands.

The existence of Rhinotermitidae, especially Coptotermes spp. and Schedorhinotermes spp., which belongs to the termites group of wood and litter eater and is a potential pest on A. crassicarpa stands. According to Hanis et al. (2014) groups of wood-eating termites are potential to be pest. Coptotermes and Schedorhinotermes are the most common termites found in the sample paths. However, genus of Schedorhinotermes is not found in A. crassicarpa stands, but it is found only in litter and tree stumps.

Longipeditermes is one of the termites from subfamily Nasutitermitinae which is often found on the floor of tropical forests (Syaukani 2013). Their activities outside the colony are often done in the morning and evening to reduce the predation risk by predators. The dark-colored body and active movement among litter make the individual of termites is not easy to find and collect. The soldier caste of this genus consists of two groups, the large soldiers (major) and small soldiers (minor). Worker caste is composed of three groups (trimorphic), namely: the major, medium, and minor workers (Syaukani 2013). Recently, three species of termites from the genus is found spreading in the Indo-Malayan subregion, L. longipes (Haviland), $L$. kistneri (Ahmad and Akhtar), and L. mandibulatus (Thapa) (Miura and Matsumoto, 1998 ). The termites are distributed in Sumatra, Peninsular Malaysia, Java, and Borneo.

The diversity of subfamily Termitinae is distinguished by the food and morphology. Based on the food source, it can be divided into two groups: wood-eating termites and humus-eating termites. Pericapritermes itself is included in the group of termites eating humus, the rest of weathered wood, and clay (Pribadi 2015). On the humus-eating termites, the soldier caste is divided into two groups based on mandible morphology: bilaterally symmetrical 
biting/slashing group and snapping group known as Capritermes group. P. mohri was found near logged tree stump and the nest was found below ground. The nest of the termites was charcoal-like (black) and very hard. According to Faszly et al. (2005), genus Pericapritermes is included in category III i.e. termites which consume humus and high organic material. The species requires a very specific habitat, so they are very difficult to find. As Haneda and Firmansyah (2012) have observed in Gunung Walat Educational Forest, Sukabumi that the genus was found only at one point. The finding is in line with the recent study.

\section{ACKNOWLEDGEMENTS}

The authors thank Directorate General of Research and Development Strengthening, the Ministry of Research, Technology and Higher Education of the Republic Indonesia on study grants given for the research. The authors also thank the members of the PT. Bukit Batu Hutani Alam of Riau, Indonesia who has facilitated and helped the study. The authors also thank Budi Tjahyono for the permit of study area and transportation facilitation during the study.

\section{REFERENCES}

ASTM. 2008. Standard Test Method of Evaluating Wood Preservatives by Field Test with Stakes. ASTM D 1758-08. American Society for Testing and Material, United States of America, Washington, DC.

Ahmad M. 1958. Key to the Indomalayan termite, Biologia Volume 4. Department of Zoology, University of the Panjab, Lahore.

Arinana, Haneda NF, Kahar TP. 2012. Diversity and distribution of termites species on oil palm plantation at the PTP Nusantara VIII Bogor-West Java Indonesia. Proceedings of the 9th Pacific-Rim Termite Research Group Conference. Hanoi, 27-28 February 2012.

Arinana, Haneda NF, Nandika D, Prawitasari WA. 2014. Damage intensity of house building and termite diversity in Perumahan Nasional Bumi Bekasi Baru, Rawalumbu Bekasi. In: The Utilization of Biomass from Forest and Plantation for Environment Conservation effort; Proceeding of the 6th International Symposium of Indonesian Wood Research Society. Medan, 12-13 November 2014. [Indonesian]

Cheng S, Kirton LG, Gurmit S. 2008. Termite attack on oil palm grown o peat soil: identification of pest status and factor contributing to the problem. Planter 84: 200-210.

Faszly R, Idris AB, Sajap AS. 2005. Termites (Insecta: Isoptera) assemblages from Sungai Bebar peat swamp forest, Pahang. In: Latiff A, Khali AH, Norhayati A, Mohd Nizam MS, Toh AN, Gill SK (eds.) Biodiversity expedition Sungai Bebar peat swamp forest: summary findings. PSF Technical Series 4: 133-140.

Gathorne-Hardy FJ, Jones DT. 2002. The recolonization of the Krakatau island by termites and their biogeographical origin. Bull J Linn Soc 71: 251-267.
Handru A, Herwina H, Dahelmi. 2012. The species of termites (Isoptera) in the forest area of Bukit Tengah Pulau and the area of palm oil plantation, South Solok. Jurnal Biologi Universitas Andalas 1 (1): 6977. [Indonesian]

Haneda NF, Firmasyah A. 2012. Termite Biodiversity in Gunung Walat Education Forest, Sukabumi. Jurnal Silvikultur Tropika 3 (2): 92-96. [Indonesian]

Hanis JA, Hassan AA, Nurita AA, Salman CMR. 2014. Community structure of termite in a hill Dipterocarp forest of Belum-Temengor forest complex, Malaysia: emergence of pest species. Raffles Bull Zool 62: 3-11.

Herlinda S, Septiana R, Irsan C, Adam T, Thalib R. 2010. Population and termite (Coptotermes curvignathus) attack in the rubber plantation in South Sumatera. Prosiding Seminar Nasional. Palembang, 13-14 Desember 2010. [Indonesian]

Hutabarat NK, Oemry S, Pinem MI. 2015. The effectiveness of botanical termiticide on termite mortality (Coptotermes curvignathus Holmgren) (Isoptera: Rhinotermitidae) in Laboratory. Jurnal Agroekoteknologi 3 (1): 103-111. [Indonesian]

Kon TW, Bong CFJ, King JHP, Leong CTS. 2012. Biodiversity of termite (Insect; Isoptera) in tropical peat land cultivated oil palm. J Biol Sci 15: $108-120$.

Lam HK, Harbard JL, Koutoulis A. 2014. Tetraploid induction of Acacia crassicarpa using colchicine and oryzalin. J Trop Sci 26 (3): 347-354.

Miura T, Matsumoto T. 1998. Open-air litter foraging in the Nasute termite Longipeditermes longipes (Isoptera: Termitidae). J Insect Behav 11: 179-189.

Nandika D, Rismayadi Y, Diba F. 2015. Termite: Biology and Control. Universitas Muhammadiyah Surakarta Press, Surakarta. [Indonesian]

Ngatiman. 2014. Attacking termite Coptotermes sp. in the red Meranti (Shorea leprosulla Miq.) at several planting sites in East Kalimantan. Jurnal Penelitian Dipterocarpa 8 (1): 59-64. [Indonesian]

Pribadi T. 2015. The assemblage of termites in the oil palm plantation in Katingan, Central Kalimantan. Pros Sem Nas Masy Biodiv Indon 1 (3): 554-559. [Indonesian]

Rismayadi Y. 1999. Study of foranging and population size of soil termite Schedinhinotermes javanicus Kemmer (Isoptera: Rhinotermitidae) and Microtermes inspiratus Kemmer (Isoptera: Termitidae) [Thesis]. Institut Pertanian Bogor, Bogor. [Indonesian]

Savitri A, Martini I, Yuliawati S. 2016. The diversity of soil termites and their impact on the house building in Mijen Resident, Malang City. Jurnal Kesehatan Masyarakat 4 (1): 100-105.

Su NY, Chouvenc T, Li HF. 2017. Potential hybridization between two invasive termite species, Coptotermes formosanus and C. gestroi (Isoptera: Rhinotermitidae), and its biological and economic implications. Jurnal Insects 8 (14): 1-8.

Subekti N. 2010. Population ccharacteristics of subterranean termite Coptotermes sp. (Blattodea: Rhinotermitidae) and the impact of his attacks. Jurnal Biosaintifika 2 (2): 110-114. [Indonesian]

Sugesty S, Kardiansyah T, Pratiwi W. 2015. Potential of Acacia crassicarpa as raw material for pulp and paper in the Industrial Plantation Forest (HTI). Jurnal Selulosa 5 (1): 21-32. [Indonesian]

Suhartati, Rahmayanto Y, Daeng Y. 2014. Impacts of reducing rotation cycle of Acacia Industrial Plantation Forest on production, ecological and social sustainability. Info Teknis Eboni 11 (2): 103-106. [Indonesian]

Sumargo W, Nanggara SG, Nainggolan FA, Apriani I. 2011. Figure of Indonesian Forest. Forest Watch Indonesia, Jakarta. [Indonesian]

Syaukani. 2013. Termites species richness and distribution at residential area in PT Arun LNG. Jurnal Natural 13 (1): 43-49.

Tho YP. 1992. Termites of Peninsular Malaysia. Kuala Lumpur. Forest Research Insitute Malaysia, Kepong. 